\title{
Gestational Diabetes and Pre-Eclampsia: Common Antecedents?
}

\begin{abstract}
Objective: To evaluate commonality of risk factor profiles of women who develop gestational diabetes and pre-eclampsia. Methods: Prospective cohort study in prenatal clinics of the Brazilian Unified Health System in six state capitals. 4.766 pregnant women between 20 to 48 years old were consecutively enrolled between $20^{\text {th }}$ and $28^{\text {th }}$ gestational weeks. Smoking habits and traditional risk factors for pre-eclampsia and gestational diabetes were obtained by the interview at enrollment. Gestational diabetes was diagnosed using a 75-g oral glucose tolerance test and pre-eclampsia through chart review. Results: Both gestational diabetes and pre-eclampsia were associated with age (OR 2.07; 95\% Cl 1.65-2.23 and OR 1.55; 95\% Cl 1.08-2.23, respectively), pre-pregnancy body mass index (OR 1.62; $95 \% \mathrm{Cl} 1.40-3.53$ and $\mathrm{OR}$ $1.83 ; 95 \% \mathrm{Cl} 1.52-4.80$, respectively) and weight gain in early pregnancy (OR 1.28; $95 \% \mathrm{Cl} 1.12-1.47$ and $\mathrm{OR} 1.27 ; 95 \% \mathrm{Cl} 1.06-1.52$, respectively). Lower odds of gestational diabetes (OR $0.31 ; 95 \% \mathrm{Cl} 0.22-0.44$ ) and pre-eclampsia (OR $0.36 ; 95 \% \mathrm{Cl} 0.20-0.51$ ) were observed in nulliparous women who have smoked during pregnancy. Conclusions: Gestational diabetes and preeclampsia share a pattern of risk factors, suggesting the possibility of common aetiology. (Arq Bras Endocrinol Metab 2008; 52/6:975-984)
\end{abstract}

Keywords: Gestational diabetes; Pre-eclampsia; Tobacco; Pregnancy; Risk factors

\section{RESUMO}

\section{Diabetes Gestacional e Pré-Eclâmpsia: Antecedentes Comuns?}

Objetivo: Avaliar a concordância do padrão de fatores de risco de mulheres que desenvolvem diabetes gestacional e pré-eclâmpsia. Métodos: Estudo de coorte prospectivo em clínicas de atendimento pré-natal do Sistema Único de Saúde de seis capitais do Brasil, 4.766 mulheres grávidas de 20 a 48 anos de idade foram arroladas de maneira consecutiva entre a $20^{\circ}$ e $28^{\circ}$ semanas de gestação. $\mathrm{O}$ hábito de fumar e os fatores de risco tradicionais para pré-eclâmpsia e diabetes gestacional foram obtidos por entrevista no arrolamento. Diabetes gestacional foi diagnosticada usando um teste oral de tolerância a glicose com $75 \mathrm{~g}$ e pré-eclâmpsia por meio de revisão de prontuário. Resultados: Diabetes gestacional e pré-eclâmpsia são associadas com idade (RC 2,07; 95\% IC 1,65-2,23 e RC 1,55; 95\% IC 1,08-2,23, respectivamente), índice de massa corporal pré-gestacional (RC 1,62; 95\% IC 1,40-3,53 e RC 1,83; $95 \%$ IC 1,52-4,80, respectivamente) e ganho de peso precocemente durante a gestação (RC 1,28; $95 \%$ IC $1,12-1,47$ e RC 1,$27 ; 95 \%$ IC 1,06-1,52, respectivamente). Menor chance de diabetes gestacional (RC 0,31; 95\% IC 0,22-0,44) e pré-eclâmpsia (RC 0,36; $95 \%$ IC 0,20-0,51) foram observados em mulheres nulíparas que fumaram durante a gestação. Conclusão: Diabetes gestacional e pré-eclâmpsia compartiIham um padrão de fatores de risco, sugerindo a possibilidade de uma etiologia comum. (Arq Bras Endocrinol Metab 2008; 52/6:975-984)

Descritores: Diabetes gestacional; Pré-eclâmpsia; Tabaco; Gravidez; Fatores de risco

\section{original}

\author{
ELIANA M. DA ROS WENDLAND \\ BRUCE B. DUNCAN \\ JosÉ M. BELIZÁN \\ AlVAROVIGO \\ MARIA INÊS SCHMIDT
}

Graduate Studies Program in Epidemiology. Faculty of Medicine. Federal University of Rio Grande do Sul, Porto Alegre, Brazil (EMRW, BBD, AV, MIS).

Department of Mother \& Child Health Research, Institute for Clinical Effectiveness and Health Policy (IECS), Buenos Aires, Argentina (JMB).

Recebido em 25/2/2008

Aceito em 4/7/2008 


\section{INTRODUCTION}

T ESTATIONAL DIABETES AND pregnancy-induced hyperItension associated with proteinuria are two of the main complications of pregnancy. Hypertensive disorders of pregnancy complicate 5 to $8 \%$ of all pregnancies and are the major causes of maternal death (1), accounting for $37 \%$ of direct maternal deaths in Brazil (2). Gestational glucose intolerance affects 1 to $16 \%$ of pregnancies and is associated with increased risk of gestational and perinatal adverse outcomes such as macrosomia, respiratory distress syndrome, fetal hyperinsulinemia and, in some settings, perinatal death (3). Pre-eclampsia has been frequently reported as a complication of gestational diabetes(4) but the relationship between these two conditions is not well understood. Several studies suggest underlying common pathophysiology, including insulin resistance, chronic inflammation and endothelial dysfunction (5-9). Common risk factors, such as elevated body mass index and advanced age have been noted for each of the two conditions (10.11).

Comparison of the risk factors for pre-eclampsia and gestational diabetes may provide insight into the etiologic mechanisms related to theses conditions. To date, most epidemiologic research has focused on gestational diabetes as a risk factor for pre-eclampsia, not directly comparing these risk factor profiles, not even documenting which risk factors are similar and to what extent they could be related.

One factor that has been consistently found to be associated with lower risk of pre-eclampsia is smoking during pregnancy (12-16). The same consistency has not been reported for gestational diabetes (17). Reanalysis of this association with both outcomes is relevant, since smoking may be linked to pathophysiologic processes for both disorders $(5,18,19)$.

Thus, we aim in this report to evaluate and compare the risk factor profile of women developing gestational diabetes and pre-eclampsia in the Brazilian Study of Gestational Diabetes, including the association of cigarette smoking with each disease.

\section{METHODS}

\section{Study population}

The Brazilian Study of Gestational Diabetes is a prospective cohort study conducted in six state capitals of Brazil (Porto Alegre, São Paulo, Rio de Janeiro, Salva- dor, Fortaleza and Manaus) between 1991 and 1994. A total of 5,564 pregnant women, aged 20 or more, without diagnosis of type 2 diabetes, were enrolled between 20 and 28 weeks of pregnancy in prenatal clinics of the Unified Health System, and were followed until delivery through chart review. Of these, we excluded 798 women classified as Asiatic (due to the small number of such subjects), having twin pregnancies, lacking information on pre-eclampsia, or not undergoing a $75 \mathrm{~g}$ oral glucose tolerance test (OGTT-75g), leaving 4766 women for analyses (Figure 1). With this sample size we would expect to obtain statistical significance $(\alpha=$ $5 \% ; \beta=20 \%$ ) in associations with relative risk of 0.70 or less between smoking during pregnancy (present in $25.5 \%$ ), and gestational diabetes (frequency of $7.5 \%$ ) and of 0.56 or less between smoking and pre-eclampsia (frequency of $3.1 \%$ ). The local ethic committee of each study centre has approved the study protocol, and patients consented to participate after being informed about the nature of the study.

\section{Definition of study variables}

A standardized interview at enrolment collected data on maternal sociodemographic characteristics, medical history and smoking habits. Skin colour was noted by the interviewer as white, black or mixed, the latter including various admixtures of European, African and native Brazilian descent. Standardized anthropometric measures were obtained, and the women were invited to undergo a standardized 2 -h 75 -g oral glucose tolerance test (OGTT) (20) between the $24^{\text {th }}$ and the $28^{\text {th }}$ gestational weeks. We abstracted data on blood pressure, urinary protein, use of anti-hypertensive medication and diagnosis of pre-eclampsia or eclampsia from medical records. Smoking habits, including quantity of ciga-

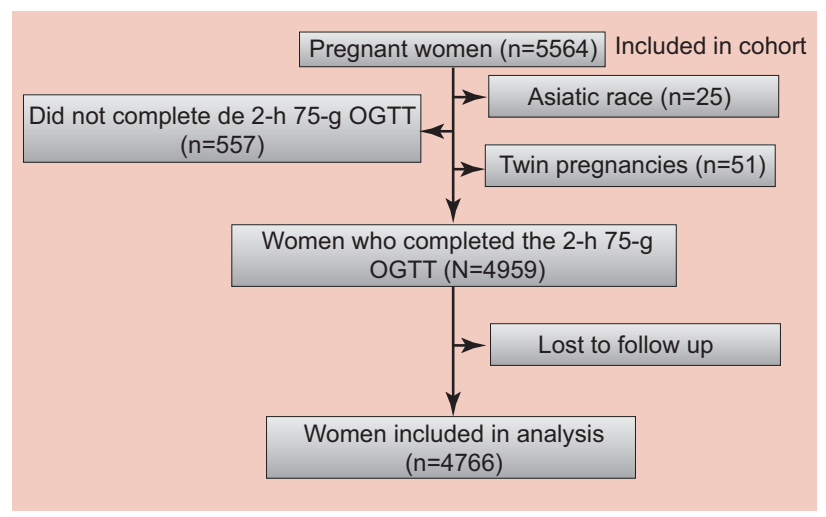

Figure 1. Study flow chart, see text for exclusions. 
rettes smoked and alterations in the habit related to pregnancy, were obtained through a structured interview at enrolment. Women were classified according with parity in nulliparas (first child) or multiparas (one or more previous children).

Weight and height were measured in duplicates at enrolment. Pre-pregnancy body mass index (BMI) was calculated using pre-pregnancy weight as reported at the interview. Weight gain was calculated subtracting prepregnancy weight from weight measured at enrolment.

Gestational diabetes was defined on the basis of the 2-h 75-g OGTT, according to WHO panel recommendations: fasting glucose $\geq 7.0 \mathrm{mmol} / \mathrm{L}$ or 2 -h glucose $\geq 7.8 \mathrm{mmol} / \mathrm{L})(2 \mathrm{l})$. Ascertainment of pre-eclampsia through chart review was based on the recommendations of the National High Blood Pressure Education
Program Working Group (14). Briefly, the definition consisted of diagnosis, after the 20th week of gestation, of either chronic or incident hypertension associated with proteinuria or convulsions (eclampsia).

Women were classified according to their current and past smoking habits at enrolment into three categories: non-smokers, those who quit before the current pregnancy, and those who have smoked during the current pregnancy.

\section{Statistical analysis}

Potential risk factors were selected on the basis of previous knowledge on their association with gestational diabetes and pre-eclampsia. Logistic regression was used to estimate the association between risk factors and the development of gestational diabetes and pre-eclampsia.

Table 1. Characteristics of pregnant women between 20 to 48 years old, according to the presence of gestational diabetes and pre-eclampsia $(n=4766)$.

\begin{tabular}{|c|c|c|c|c|c|}
\hline \multirow[t]{2}{*}{ Characteristic } & \multirow[t]{2}{*}{ Total $^{*}$} & \multicolumn{2}{|c|}{ Gestational diabetes } & \multicolumn{2}{|c|}{ Pre-eclampsia } \\
\hline & & Present & Absent & Present & Absent \\
\hline Pre-eclampsia & $148(3.1)$ & $22(14.9)$ & $126(7.3)$ & & \\
\hline Gestational diabetes & $359(7.5)$ & & & $22(6.1)$ & $337(2.9)$ \\
\hline \multicolumn{6}{|l|}{ Skin colour } \\
\hline White & $2128(44.7)$ & $202(9.1)$ & $2022(90.9)$ & $75(3.5)$ & $2053(96.5)$ \\
\hline Black & $653(13.7)$ & $31(4.6)$ & $647(95.4)$ & $31(4.8)$ & $622(95.3)$ \\
\hline Mixed & $1984(41.6)$ & $139(6.8)$ & 1895 (93.2) & $42(2.1)$ & $1942(97.9)$ \\
\hline \multicolumn{6}{|l|}{ Study centre } \\
\hline Porto Alegre & $1025(21.5)$ & $75(7.3)$ & $950(92.7)$ & $39(3.8)$ & $986(96.2)$ \\
\hline Salvador & $818(17.2)$ & $29(3.5)$ & 789 (96.5) & $24(2.9)$ & $794(97.1)$ \\
\hline Fortaleza & $983(20.6)$ & $82(8.3)$ & 901 (91.7) & $23(2.3)$ & $960(97.7)$ \\
\hline Rio de Janeiro & $479(10.1)$ & $58(11.9)$ & $421(87.9)$ & $22(4.6)$ & $457(95.4)$ \\
\hline São Paulo & $1053(22.1)$ & $77(7.6)$ & $976(93.0)$ & $39(3.7)$ & $1014(96.3)$ \\
\hline Manaus & $408(8.6)$ & $38(9.0)$ & 370 (90.7) & $1(0.3)$ & $407(99.7)$ \\
\hline \multicolumn{6}{|l|}{ Parity } \\
\hline Nulliparas & $1305(30.7)$ & $96(7.3)$ & 1209 (92.6) & $62(4.7)$ & $1243(95.3)$ \\
\hline 1-2 delivery & $2249(52.3)$ & $170(7.7)$ & $2054(92.4)$ & $49(2.2)$ & $2175(97.8)$ \\
\hline$\geq 3$ deliveries & $720(17.0)$ & $51(7.2)$ & $669(92.9)$ & $21(2.9)$ & $699(97.1)$ \\
\hline \multicolumn{6}{|l|}{ Smoking habits } \\
\hline Not smoking & $2836(59.5)$ & $227(7.5)$ & 2609 (92.5) & $96(3.4)$ & $2740(96.6)$ \\
\hline Quitting before pregnancy & $716(15.0)$ & $53(7.4)$ & $663(92.6)$ & $27(3.8)$ & $689(96.2)$ \\
\hline Smoking during pregnancy & $1214(25.5)$ & $79(6.5)$ & $1134(93.5)$ & $25(2.1)$ & $1189(97.9)$ \\
\hline Age (years) & $27.8(5.4)$ & $30.1(6.0)$ & $27.6(5.4)$ & $29.3(5.4)$ & $27.7(5.4)$ \\
\hline Pre-pregnancy body mass index $\left(\mathrm{kg} / \mathrm{m}^{2}\right)$ & $23.4(4.1)$ & $24.9(4.5)$ & $23.2(4.0)$ & $25.7(5.4)$ & $23.3(4.0)$ \\
\hline Waist circumference $(\mathrm{cm})$ & $82.2(8.2)$ & $85.8(9.4)$ & $81.9(8.1)$ & $86.8(9.8)$ & $82.0(8.1)$ \\
\hline Weight gain in pregnancy (kg) & $6.5(4.9)$ & $6.9(5.5)$ & $6.4(4.9)$ & $6.8(6.1)$ & $6.4(4.9)$ \\
\hline
\end{tabular}


For multivariable models, variables were chosen based on the statistical significance $(p>0.10)$ of their unadjusted association with at least one of these outcomes.

The Wald statistic for the interaction term was used to test interaction, having the significance level being defined as $10 \%$. Collinearity across independent variables was investigated with linear regression models, using as criterion a variance inflation factor greater than 3 .

Adjusted means were estimated by analysis of covariance (ANCOVA), taking into account age, body mass index, weight gain during pregnancy, race, study centre, and parity. Tukey's test was used for multiple comparisons. All analyses were performed using Statistical Analysis System (SAS) version 8.2 and our results were reported following the STROBE statement (22).

\section{RESULTS}

Among the women studied, 148 (3.1\%) were ascertained as having pre-eclampsia or eclampsia and $359(7.5 \%)$ as having gestational diabetes, virtually all of the latter, by $2 \mathrm{~h}$ post-load glycaemia $\geq 7.8 \mathrm{mmol} / \mathrm{L}$. General characteristics overall and according to the presence of gestational diabetes or pre-eclampsia are presented in Table 1. The frequency of the two conditions varied substantially according to skin colour, study centre, parity and smoking habits categories. Approximately one third of the women were nulliparas. The mean gestational age at enrolment was $24 \pm 2.8$ weeks. Included women were similar to the 798 excluded in terms of age, pre-pregnancy body mass index, weight gain, smoking status and the prevalence of gestational diabetes and pre-eclampsia (data not shown). Studied women were more frequently white ( 45 vs. $40 \%$ ) and nulliparous ( 31 vs. $26 \%$ ).

The prevalence of smoking during pregnancy was $26 \%$, and $15 \%$ of women reported quitting smoking prior to pregnancy. Among those who continued to smoke during pregnancy, most $(76.4 \%)$ were classified as light smokers (less then 9 cigarettes/day) and $6.3 \%$ being classified as heavy smokers ( $\geq 20$ cigarettes/day).

Table 2. Crude and adjusted* odds ratios (OR) for associations of risk factors with pre-eclampsia and gestational diabetes among 4766 pregnant women, 1991 a 1995.

\begin{tabular}{|c|c|c|c|c|c|c|c|c|}
\hline \multirow[t]{3}{*}{ Risk factors } & \multicolumn{4}{|c|}{ Gestational diabetes $(n=359)$} & \multicolumn{4}{|c|}{ Pre-eclampsia $(n=148)$} \\
\hline & \multicolumn{2}{|c|}{ Crude } & \multicolumn{2}{|c|}{ Adjusted* } & \multicolumn{2}{|c|}{ Crude } & \multicolumn{2}{|c|}{ Adjusted* } \\
\hline & OR & $95 \% \mathrm{Cl}$ & OR & $95 \% \mathrm{Cl}$ & OR & $95 \% \mathrm{Cl}$ & OR & $95 \% \mathrm{Cl}$ \\
\hline Gestational diabetes & & & & & 2.22 & $1.39-3.53$ & & \\
\hline Pre-eclampsia & 2.22 & $1.39-3.54$ & & & & & & \\
\hline Age (each 10 years) & 2.21 & $2.17-2.56$ & 2.07 & $1.65-2.60$ & 1.62 & $1.22-2.15$ & 1.55 & $1.08-2.23$ \\
\hline $\begin{array}{l}\text { Pre-pregnancy BMl }\left(\mathrm{kg} / \mathrm{m}^{2}\right) \text { - } \\
\text { each } 5 \text { units }\end{array}$ & 1.52 & $1.35-2.90$ & 1.62 & $1.40-3.53$ & 1.72 & $1.47-2.02$ & 1.83 & $1.52-4.86$ \\
\hline Weight gain (kg) - interquartile range & 1.10 & $0.98-1.24$ & 1.28 & $1.12-1.47$ & 1.08 & $0.90-1.30$ & 1.27 & $1.06-1.52$ \\
\hline \multicolumn{9}{|l|}{ Skin colour } \\
\hline White & 1.0 & & 1.0 & & 1.0 & & 1.0 & \\
\hline Black & 0.49 & $0.33-0.72$ & 0.41 & $0.26-0.66$ & 1.36 & $0.89-2.09$ & 1.14 & $0.69-1.89$ \\
\hline Mixed & 0.75 & $0.60-0.94$ & 0.82 & $0.60-1.11$ & 0.59 & $0.40-0.87$ & 0.74 & $0.45-1.21$ \\
\hline \multicolumn{9}{|l|}{ Study centre } \\
\hline Porto Alegre & 1.0 & & 1.0 & & 1.0 & & 1.0 & \\
\hline Salvador & 0.47 & $0.30-0.72$ & 0.49 & $0.28-0.84$ & 0.76 & $0.46-1.28$ & 0.73 & $0.37-1.43$ \\
\hline Fortaleza & 1.15 & $0.83-1.60$ & 1.43 & $0.97-2.10$ & 0.61 & $0.36-1.02$ & 0.68 & $0.36-1.27$ \\
\hline Rio de Janeiro & 1.75 & $1.22-2.51$ & 1.31 & $0.86-1.97$ & 1.22 & $0.71-2.08$ & 1.02 & $0.55-1.89$ \\
\hline Sao Paulo & 1.00 & $0.72-1.39$ & 0.65 & $0.45-0.94$ & 0.97 & $0.62-1.53$ & 0.72 & $0.43-1.18$ \\
\hline Manaus & 1.30 & $0.87-1.96$ & & & 0.06 & $0.01-0.45$ & & \\
\hline \multicolumn{9}{|l|}{ Parity (n) } \\
\hline Nulliparas & 1.0 & & 1.0 & & 1.0 & & 1.0 & \\
\hline 1-2 deliveries & 1.04 & $0.80-1.35$ & 0.80 & $0.59-1.08$ & 0.45 & $0.31-0.66$ & 0.33 & $0.22-0.50$ \\
\hline$\geq 3$ deliveries & 0.96 & $0.68-1.37$ & 0.53 & $0.34-0.83$ & 0.60 & $0.36-1.00$ & 0.31 & $0.16-0.57$ \\
\hline \multicolumn{9}{|l|}{ Smoking habits } \\
\hline Not smoking & 1.0 & & 1.0 & & 1.0 & & 1.0 & \\
\hline Quitting before pregnancy & 0.92 & $0.67-1.25$ & 0.75 & $0.52-1.09$ & 1.12 & $0.72-1.73$ & 1.20 & $0.73-1.95$ \\
\hline Smoking during pregnancy & 0.80 & $0.61-1.04$ & 0.69 & $0.50-0.96$ & 0.48 & $0.27-0.85$ & 0.68 & $0.41-1.11$ \\
\hline
\end{tabular}

* Adjusted for all other variables in the table in 3713 women after 408 from Manaus and 644 with missing values were excluded (see text). 
Crude and adjusted odds ratios for various putative risk factors for gestational diabetes and pre-eclampsia are shown in Table 2. A common pattern of associations was seen for age, BMI, waist circumference and early pregnancy weight gain. Additionally, each condition predicted the other. Due to a very small number of pre-eclampsia cases in Manaus, data was excluded from this centre in multiple logistic regression analysis. Table 2 shows that, in models simultaneously investigating age, pre-pregnancy BMI, early pregnancy weight gain, parity, study centre and smoking, the first three factors were associated with higher odds of developing both gestational diabetes and pre-eclampsia. Interestingly, smokers during pregnancy showed a tendency toward protection for both gestational diabetes $(\mathrm{OR}=0.69 ; 95 \% \mathrm{CI} 0.50-0.96)$ and pre-eclampsia $(\mathrm{OR}=0.68 ; 95 \%$ CI $0.41-1.11)$.

As an interaction between smoking and parity was detected for each outcome ( $\mathrm{p}=0.061$ for gestational diabetes and $\mathrm{p}=0.059$ for pre-eclampsia), further analyses was conduted separately for nulliparas and multiparas (Table 3). Smoking during pregnancy was associated with a lower odds of developing gestational diabetes and pre-eclampsia, especially so among nulliparous women (Figure 2). The patterns of the association between smoking and gestational diabetes and pre-eclampsia were similar, with significantly lower odds ratios for gestational diabetes $(\mathrm{OR}=0.31$; 95\% CI 0.22-0.44) and for preeclampsia $(\mathrm{OR}=0.36$; 95\% CI $0.20-0.5 \mathrm{l})$ in nulliparous women who have smoked during pregnancy.

Table 4 shows the adjusted means for glucose concentrations at each time point during the oral glucose tolerance test. While there were no significant differences in fasting and $\mathrm{l}$-h plasma glucose means, those for $2 \mathrm{~h}$ glucose were significantly lower in smokers $(5.58 \pm 0.03 \mathrm{mmol} / \mathrm{L}) \mathrm{com}$ pared to non-smokers $(5.77 \pm 0.04 \mathrm{mmol} / \mathrm{L}), \mathrm{p}<0.01$.

It was additionally investigated the association of smoking with gestational diabetes when the latter was defined according to the American Diabetes Association (at least two values greater than or equal to a fasting glucose of $5.3 \mathrm{mmol} / \mathrm{l}$, a $1 \mathrm{~h}$ glucose of $10.0 \mathrm{mmol} / \mathrm{L}$, or a $2 \mathrm{~h}$ glucose of $8.6 \mathrm{mmol} / \mathrm{L}(23)$. With this more stringent definition, only 120 cases were ascertained. With full adjustment (for age, skin colour, pre-pregnancy BMI, weight gain during pregnancy and parity), gestational diabetes was not associated with smoking during

Table 3. Adjusted* associations of risk factors with gestational diabetes and pre-eclampsia according to parity, based on 4358 pregnancies ${ }^{\dagger}$ between 1991 and 1995.

\begin{tabular}{|c|c|c|c|c|c|c|c|c|}
\hline & \multicolumn{4}{|c|}{ Gestational diabetes (271) } & \multicolumn{4}{|c|}{ Pre-eclampsia (123) } \\
\hline & \multicolumn{2}{|c|}{ Multiparas (186) } & \multicolumn{2}{|c|}{ Nulliparas (85) } & \multicolumn{2}{|c|}{ Multiparas (62) } & \multicolumn{2}{|c|}{ Nulliparas (61) } \\
\hline & OR & $95 \% \mathrm{Cl}$ & OR & $95 \% \mathrm{Cl}$ & OR & $95 \% \mathrm{Cl}$ & OR & $95 \% \mathrm{Cl}$ \\
\hline Age (years) & 1.08 & $1.05-1.11$ & 1.04 & $0.99-1.09$ & 1.04 & $0.99-1.09$ & 1.05 & $0.99-1.10$ \\
\hline Pre-pregnancy BMl (kg/m²) & 1.10 & $1.06-1.14$ & 1.11 & $1.06-1.17$ & 1.13 & $1.07-1.19$ & 1.13 & $1.07-1.19$ \\
\hline Weight gain (kg) & 1.03 & $1.00-1.07$ & 1.08 & $1.03-1.13$ & 1.02 & $0.98-1.07$ & 1.07 & $1.02-1.13$ \\
\hline \multicolumn{9}{|l|}{ Skin color } \\
\hline White & 1.0 & & 1.0 & & 1.0 & & 1.0 & \\
\hline Black & 0.42 & $0.25-0.73$ & 0.36 & $0.13-0.95$ & 1.38 & $0.72-2.63$ & 0.91 & $0.40-2.07$ \\
\hline Mixed & 0.73 & $0.51-1.06$ & 1.07 & $0.61-1.88$ & 0.62 & $0.31-1.23$ & 0.98 & $0.47-2.00$ \\
\hline \multicolumn{9}{|l|}{ Study Center } \\
\hline Porto Alegre & 1.0 & & 1.0 & & 1.0 & & 1.0 & \\
\hline Salvador & 0.53 & $0.27-1.02$ & 0.38 & $0.14-1.06$ & 0.78 & $0.31-1.92$ & 0.59 & $0.22-1.74$ \\
\hline Fortaleza & 1.70 & $1.07-2.70$ & 1.00 & $0.49-1.98$ & 1.11 & $0.50-2.46$ & 0.37 & $0.14-0.99$ \\
\hline Rio de Janeiro & 1.45 & $0.92-2.30$ & 1.15 & $0.41-3.26$ & 0.90 & $0.41-2.01$ & 1.53 & $0.55-4.25$ \\
\hline Sao Paulo & 0.79 & $0.51-1.21$ & 0.63 & $0.34-1.18$ & 0.61 & $0.30-1.27$ & 0.72 & $0.36-1.43$ \\
\hline \multicolumn{9}{|l|}{ Smoking habits } \\
\hline Not smoking & 1.0 & & 1.0 & & 1.0 & & 1.0 & \\
\hline Quitting before pregnancy & 0.58 & $0.36-0.92$ & 1.36 & $0.73-2.52$ & 1.03 & $0.52-2.05$ & 1.50 & $0.71-3.00$ \\
\hline Smoking during pregnancy & 0.80 & $0.56-1.15$ & 0.31 & $0.13-0.75$ & 0.91 & $0.49-1.67$ & 0.34 & $0.12-0.89$ \\
\hline
\end{tabular}

*Derived from multiple logistic regression analysis adjusted for all other variables in the table; 'Excluding 421 women from Manaus. 

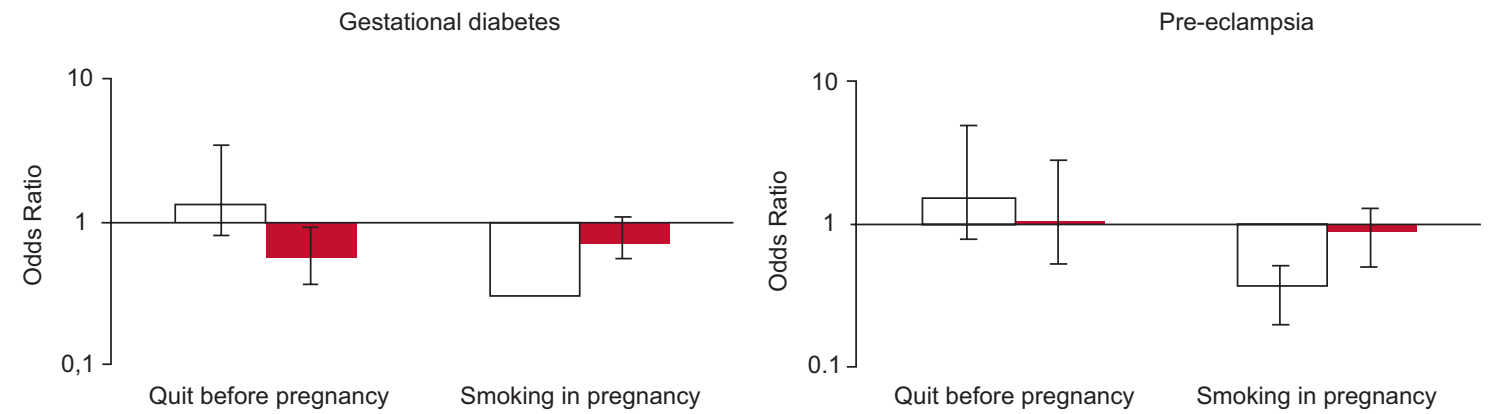

Figure 2. Heterogeneity in the associations of gestational diabetes (a) and pre-eclampsia (b) with smoking habits by parity: nulliparas, open columns; multiparas, filled columns. Odds ratio for interaction and $95 \%$ confidence intervals adjusted for maternal age, pre-pregnancy body mass index, weight gain during pregnancy, study centre and race. Reference group is nonsmokers.

Table 4. Adjusted fasting, 1-hour and 2-hour glucose means during a 75-g oral glucose tolerance test, according to smoking categories in pregnant women between 1991 a 1995.

\begin{tabular}{|c|c|c|c|c|c|c|}
\hline \multirow[b]{3}{*}{ Smoking habits } & \multicolumn{6}{|c|}{ Glucose concentration (mmol/L) } \\
\hline & \multicolumn{2}{|c|}{ Fasting } & \multicolumn{2}{|c|}{1 hour } & \multicolumn{2}{|c|}{2 hour } \\
\hline & Mean & (SD) & Mean & (SD) & Mean & (SD) \\
\hline Not smoking ${ }^{\dagger}$ & 4.44 & $(0.01)$ & 6.71 & $(0.04)$ & 5.77 & $(0.03)$ \\
\hline Quitting before pregnancy & 4.48 & $(0.02)$ & 6.65 & $(0.06)$ & 5.72 & $(0.05)$ \\
\hline Smoking during pregnancy & 4.48 & $(0.02)$ & 6.67 & $(0.05)$ & 5.58 & $(0.04)^{*}$ \\
\hline
\end{tabular}

*Statistical testing of differences between groups performed with ANCOVA (Tukey's test for multiple comparisons) adjusting for study centre, age, skin colour, body mass index, weight gain and parity. Different from reference category at $\mathrm{p}<0.01 .{ }^{\dagger}$ Reference category.

pregnancy overall $(\mathrm{OR}=1.09 ; 95 \% \mathrm{CI} 0.67-1.77)$ nor in nulliparas $(\mathrm{OR}=0.32 ; 95 \% \mathrm{CI} 0.07-1.42)$.

\section{DISCUSSION}

The results from this study demonstrate that gestational diabetes and pre-eclampsia have a similar profile of risk factors - the frequency of each increasing with age and adiposity, and decreasing with parity. Cigarette smoking during pregnancy is independently associated with lower $2 \mathrm{~h}$ post-load plasma glucose and, similarly to that of pre-eclampsia, the prevalence of gestational diabetes was inversely associated with smoking during pregnancy in nulliparous women, independent of adiposity. The associations found for age, pre-pregnancy body mass and pregnancy weight gain corroborate those previously reported independently for each disease (24). Like others, it was found an increased risk of developing pre-eclampsia in nulliparous women (25).
To date, most epidemiologic studies investigating the relationship of gestational diabetes with preeclampsia have considered gestational diabetes as a risk factor for pre-eclampsia (5.26). However, results here presented regarding similarity of risk profiles and current knowledge on similar metabolic, vascular and immune abnormalities support the concept of a common soil of causality for these two diseases. Increased insulin resistance, a characteristic of gestational diabetes (27), has also been associated with the development of preeclampsia (28-30). Similarly, abnormal endothelial function with impaired flow mediated dilatation (3133 ) and inflammatory cytokine release as C-reactive protein and $\mathrm{E}$-selectin are reported in both conditions (34-38).

Pregnancy can act as a challenge, unmasking abnormalities in the regulation of glycaemia and blood pressure. Women who have had gestational diabetes or pre-eclampsia have an increased risk of develop type 2 
diabetes (39.40), as well as hypertension and cardiovascular disease (41-43).

The clustering of risk factors, including hyperglycaemia and hypertension - the so-called metabolic syndrome - suggests a common soil of causality in the pathogenesis of diabetes and atherosclerotic cardiovascular diseases and has generated great interest over the past two decades (44-46). Our data, together with the literature, support the existence of a similar phenomenon in pregnancy. Although our investigation lacks data on dyslipidemia, it has shown important associations between three metabolic syndrome elements in pregnancy - hypertension, diabetes and obesity, demonstrating associations in pregnancy with risk factors for the metabolic syndrome - increased age, baseline obesity and weight gain. As mentioned above, much like with the metabolic syndrome outside of pregnancy (47), endothelial dysfunction and systemic inflammation are associated with this complex in pregnancy (48). Further, hypertriglyceridemia and low HDL-C have been associated with both gestational diabetes (49) and pre-eclampsia (50). Thus, the increased risk of pre-eclampsia in women with gestational diabetes may be reflecting an underlying common pathophysiology related to the metabolic syndrome outside of pregnancy. Although gestational diabetes and pre-eclampsia have each been postulated to be an early expression of metabolic syndrome (51-54), our report provides epidemiological evidence for common risk factors in pregnancy for both diseases.

Smoking was associated with lower risk of preeclampsia in many studies (55-59). The results of individual studies where confirmed in two meta-analyses, with summary relative risks of 0.68 (95\% CI 0.67-0.69)(60) and 0.51 (95\% CI 0.37-0.63) (61), respectively. Smoking as a risk factor for gestational diabetes has been less studied, with mixed findings. A study (62), different from ours, found increased risk with smoking, while others found no statistically significant association (63-65). Fatness has been associated with a greater frequency of gestational diabetes (66.67) and is inversely associated with smoking habits (68.69). The lack of adjustments for pregnancy weight gain in other studies may in part explain differences in relation to our results.

Our findings have a certain biological plausibility. Systemic inflammation with release of inflammatory cytokines has been shown to be associated with insulin resistance and an increased prevalence of gestational diabetes (70-73). Nicotine has been shown to block the release of inflammatory cytokines, suppressing the phosphorylation of molecules responsible for the inhibition of insulin action through a series of transcriptional events mediated by the NFkB or JNC pathways (74.75), as well as endothelial activation and leukocyte recruitment (76). Thus, cigarette smoking, by inhibiting inflammatory activity linked to insulin resistance, could diminish hyperglycaemia. This hypothesis do not exclude that smoking could be associated to diabetes in other specific population groups, through different metabolic pathways (77).

The strengths of our study include its relatively large, multiracial study population, its standardized oral glucose tolerance test, and its prospective study design, risk factors being measured independently of the outcomes. Study size permitted the investigation of interactions, finding statistically significant interactions for smoking and parity with the two diseases.

Some limitations to our study should be noted. It was used medical records to diagnose pre-eclampsia. As such, ascertainment of pre-eclampsia was performed in a clinical, rather than a research context. Although we cannot exclude misclassification within this context, medical registry has acceptable validity for etiologic studies (78) and it is unlike that we missed severe pre-eclampsia or eclampsia cases. The prevalence of pre-eclampsia in our study, $3.1 \%$, is consistent with other reports from developing countries (79). The small number of pre-eclampsia cases in Manaus could be due to misclassification of cases or real differences in population characteristics, deserving future research. It was also used self-reported weight to calculate pre-pregnancy BMI. Although this may have increased inaccuracy, our results confirm previous observations of an association of BMI with both pre-eclampsia and gestational diabetes (80.81). Thus, we feel that limitations in the quality of our data are unlikely to have produced the results found. We cannot exclude misclassification bias with respect to smoking, as assessment was obtained through self-report. Given smoking's well-known major adverse effects during pregnancy, self-report measures of smoking may underestimate the true prevalence. How this may have affected our results is difficult to conclude. Finally, the association reported is limited to $2 \mathrm{~h}$ glycaemia and, though statistically significant, it is not highly so. Additional studies are necessary for its confirmation.

In conclusion, data from the Brazilian Study of Gestational Diabetes has demonstrated that gestational diabetes and pre-eclampsia share common risk factors. 
This concept may be better than that of considering one disease as a risk factor for the other, as there are potential links between the two diseases reflecting common underlying pathophysiology. Both are associated with lower post load glycaemia and gestational diabetes prevalence in nulliparas who have smoked during pregnancy. Epidemiological and laboratory studies with a focus on promising pathways are needed to confirm these associations.

Acknowledgements: We would like to thank all subjects that voluntarily participated in the study and the members of the Brazilian Gestational Diabetes Study Group. Disclosure of interests: the authors did not receive any direct or indirect incentive from the tobacco industry or other commercial sources. The authors have no conflict of interests at all. This study was supported in part by the Brazilian Ministry of Health, FAPERGS (Foundation for the Support of Research of the State of Rio Grande do Sul), $\mathrm{CNPq}$ (the Brazilian National Council for Technologic and Scientific Development) through the PRONEX program (Award for Groups of Excellence), CAPES (the Brazilian Ministry of Education) and the Bristol-Myers Squibb Foundation.

\section{REFERENCES}

1. ACOG practice bulletin. Diagnosis and management of preeclampsia and eclampsia. Number 33, January 2002. American College of Obstetricians and Gynecologists. Int J Gynaecol Obstet. 2002;77:67-75.

2. Laurenti R, Jorge MHP, Gotlieb SLD. Maternal mortality in Brazilian State Capitals: some characteristics and estimates for an adjustment factor. Rev Bras Epidemiologia. 2006;7:449-60.

3. King $\mathrm{H}$. Epidemiology of glucose intolerance and gestational diabetes in women of childbearing age. Diabetes Care. 1998;21 Suppl 2:B9-13.

4. Vambergue A, Nuttens MC, Goeusse P, Biausque S, Lepeut M, Fontaine P. Pregnancy induced hypertension in women with gestational carbohydrate intolerance: the diagest study. Eur J Obstet Gynecol Reprod Biol. 2002;102:31-5.

5. Ostlund I, Haglund B, Hanson U. Gestational diabetes and preeclampsia. Eur J Obstet Gynecol Reprod Biol. 2004;113:12-6.

6. Bryson CL, loannou GN, Rulyak SJ, Critchlow C. Association between gestational diabetes and pregnancy-induced hypertension. Am J Epidemiol. 2003;158:1148-53.

7. Borzychowski AM, Sargent IL, Redman CW. Inflammation and pre-eclampsia. Semin Fetal Neonatal Med. 2006;11:309-16.

8. Roberts JM, Gammill H. Insulin resistance in preeclampsia. Hypertension. 2006;47:341-2.

9. Solomon CG, Seely EW. Brief review: hypertension in pregnancy : a manifestation of the insulin resistance syndrome? Hypertension. 2001;37:232-9.
10. Duckitt K, Harrington D. Risk factors for pre-eclampsia at antenatal booking: systematic review of controlled studies. BMJ. 2005;330:565.

11. Hollander MH, Paarlberg KM, Huisjes AJ. Gestational Diabetes: A Review of the Current Literature and Guidelines. Obstet Gynecol Surv. 2007;62:125-36.

12. Conde-Agudelo A, Althabe F, Belizan JM, Kafury-Goeta AC. Cigarette smoking during pregnancy and risk of pre-eclampsia: a systematic review. Am J Obstet Gynecol. 1999;181: 1026-35.

13. Conde-Agudelo A, Belizan JM. Risk factors for pre-eclampsia in a large cohort of Latin American and Caribbean women. BJOG. 2000;107:75-83.

14. Yang Q, Wen SW, Smith GN, Chen Y, Krewski D, Chen XK, et al. Maternal cigarette smoking and the risk of pregnancy-induced hypertension and eclampsia. Int J Epidemiol. 2006;35:288-93.

15. Odegard RA, Vatten LJ, Nilsen ST, Salvesen KA, Austgulen R. Risk factors and clinical manifestations of pre-eclampsia. BJOG. 2000;107:1410-6.

16. Hammoud AO, Bujold E, Sorokin Y, Schild C, Krapp M, Baumann P. Smoking in pregnancy revisited: findings from a large population-based study. Am J Obstet Gynecol. 2005;192:1856-62.

17. England LJ, Levine RJ, Qian C, Soule LM, Schisterman EF, Yu $\mathrm{KF}$, et al. Glucose tolerance and risk of gestational diabetes mellitus in nulliparous women who smoke during pregnancy. Am J Epidemiol. 2004;160:1205-13.

18. Roberts JM, Gammill H. Insulin resistance in preeclampsia. Hypertension. 2006;47:341-2.

19. Bryson CL, loannou GN, Rulyak SJ, Critchlow C. Association between gestational diabetes and pregnancy-induced hypertension. Am J Epidemiol. 2003;158:1148-53.

20. WHO Expert Committee on Diabetes Mellitus. Diabetes Mellitus. Tech Rep Ser. 1985;727.

21. Alberti KG, Zimmet PZ. Definition, diagnosis and classification of diabetes mellitus and its complications. Part 1: diagnosis and classification of diabetes mellitus provisional report of a WHO consultation. Diabet Med. 1998;15:539-53.

22. von Elm E, Altman DG, Egger M, Pocock SJ, Gotzsche PC, Vandenbroucke JP. Strengthening the Reporting of Observational Studies in Epidemiology (STROBE) statement: guidelines for reporting observational studies. BMJ. 2007;335:806-8.

23. American Diabetes Association. Gestational diabetes mellitus. Diabetes Care. 2000;23 Suppl 1:S77-9.

24. Doherty DA, Magann EF, Francis J, Morrison JC, Newnham JP. Pre-pregnancy body mass index and pregnancy outcomes. Int J Gynaecol Obstet. 2006;95:242-7.

25. Xiong X, Wang FL, Davidge ST, Demianczuk NN, Mayes DC, Olson DM et al. Maternal smoking and preeclampsia. J Reprod Med. 2000;45:727-32.

26. Vambergue A, Nuttens MC, Goeusse P, Biausque S, Lepeut M, Fontaine P. Pregnancy induced hypertension in women with gestational carbohydrate intolerance: the diagest study. Eur J Obstet Gynecol Reprod Biol. 2002;102:31-5.

27. Ryan EA, O'Sullivan MJ, Skyler JS. Insulin action during pregnancy. Studies with the euglycemic clamp technique. Diabetes. 1985;34:380-9.

28. Solomon CG, Seely EW. Brief review: hypertension in pregnancy : a manifestation of the insulin resistance syndrome? Hypertension. 2001;37:232-9.

29. Kaaja RJ, Greer IA. Manifestations of chronic disease during pregnancy. JAMA 2005; 294(21):2751-2757. 
30. Parretti E, Lapolla A, Dalfra M, Pacini G, Mari A, Cioni R, et al. Preeclampsia in lean normotensive normotolerant pregnant women can be predicted by simple insulin sensitivity indexes. Hypertension. 2006;47:449-53.

31. Dadelszen PV, Magee LA, Marshall JC, Rotstein OD. The Maternal Syndrome of Preeclampsia: A forme fruste of the Systemic Inflammatory Response Syndrome. Sepsis. 2007;4:43-7.

32. Paradisi G, Biaggi A, Ferrazzani S, De Carolis S, Caruso A. Abnormal carbohydrate metabolism during pregnancy: association with endothelial dysfunction. Diabetes Care. 2002;25: 560-4.

33. Chambers JC, Fusi L, Malik IS, Haskard DO, De Swiet M, Kooner JS. Association of maternal endothelial dysfunction with preeclampsia. JAMA. 2001;285:1607-12.

34. Thadhani R, Ecker JL, Mutter WP, Wolf M, Smirnakis KV, Sukhatme VP et al. Insulin resistance and alterations in angiogenesis: additive insults that may lead to preeclampsia. Hypertension. 2004;43:988-92.

35. Wolf M, Sauk J, Shah A, Vossen SK, Jimenez-Kimble R, Ecker $\mathrm{JL}$ et al. Inflammation and glucose intolerance: a prospective study of gestational diabetes mellitus. Diabetes Care. 2004;27:21-7.

36. Kautzky-Willer A, Fasching P, Jilma B, WaldhausI W, Wagner OF. Persistent elevation and metabolic dependence of circulating E-selectin after delivery in women with gestational diabetes mellitus. J Clin Endocrinol Metab. 1997;82:4117-21.

37. Aydin S, Benian A, Madazli R, Uludag S, Uzun H, Kaya S. Plasma malondialdehyde, superoxide dismutase, $\mathrm{sE}$-selectin, fibronectin, endothelin-1 and nitric oxide levels in women with preeclampsia. Eur J Obstet Gynecol Reprod Biol. 2004;113:21-5.

38. Kim SY, Ryu HM, Yang JH, Kim MY, Ahn HK, Lim HJ et al. Maternal serum levels of VCAM-1, ICAM-1 and E-selectin in preeclampsia. J Korean Med Sci. 2004;19:688-92.

39. Ben-Haroush A, Yogev Y, Hod M. Epidemiology of gestational diabetes mellitus and its association with Type 2 diabetes. Diabet Med. 2004;21:103-13.

40. Libby G, Murphy DJ, McEwan NF, Greene SA, Forsyth JS, Chien PW, et al. Pre-eclampsia and the later development of type 2 diabetes in mothers and their children: an intergenerational study from the Walker cohort. Diabetologia. 2007;50:523-30.

41. Kaaja RJ, Greer IA. Manifestations of chronic disease during pregnancy. JAMA. 2005;294:2751-7.

42. Rodie VA, Freeman DJ, Sattar N, Greer IA. Pre-eclampsia and cardiovascular disease: metabolic syndrome of pregnancy? Atherosclerosis. 2004;175:189-202.

43. Davis CL, Gutt M, Llabre MM, Marks JB, O'Sullivan MJ, Potter JE et al. History of gestational diabetes, insulin resistance and coronary risk. J Diabetes Complications. 1999;13:216-23.

44. Qiao Q, Gao W, Zhang L, Nyamdorj R, Tuomilehto J. Metabolic syndrome and cardiovascular disease. Ann Clin Biochem. 2007;44:232-63.

45. Lakka HM, Laaksonen DE, Lakka TA, Niskanen LK, Kumpusalo $E$, Tuomilehto J, et al. The metabolic syndrome and total and cardiovascular disease mortality in middle-aged men. JAMA. 2002;288:2709-16.

46. Rana JS, Nieuwdorp M, Jukema JW, Kastelein JJ. Cardiovascular metabolic syndrome - an interplay of, obesity, inflammation, diabetes and coronary heart disease. Diabetes Obes Metab. 2007;9:218-32.

47. Rana JS, Nieuwdorp M, Jukema JW, Kastelein JJ. Cardiovascular metabolic syndrome - an interplay of, obesity, inflamma- tion, diabetes and coronary heart disease. Diabetes Obes Metab. 2007;9:218-32.

48. Redman CW, Sargent IL. Pre-eclampsia, the placenta and the maternal systemic inflammatory response--a review. Placenta. 2003;24 Suppl A:S21-7.

49. Couch SC, Philipson EH, Bendel RB, Pujda LM, Milvae RA, Lammi-Keefe CJ. Elevated lipoprotein lipids and gestational hormones in women with diet-treated gestational diabetes mellitus compared to healthy pregnant controls. J Diabetes Complications. 1998;12:1-9.

50. Belo L, Caslake M, Gaffney D, Santos-Silva A, Pereira-Leite L, Quintanilha $A$ et al. Changes in LDL size and HDL concentration in normal and preeclamptic pregnancies. Atherosclerosis. 2002;162:425-32.

51. Kaaja RJ, Greer IA. Manifestations of chronic disease during pregnancy. JAMA. 2005;294:2751-7.

52. Rodie VA, Freeman DJ, Sattar N, Greer IA. Pre-eclampsia and cardiovascular disease: metabolic syndrome of pregnancy? Atherosclerosis. 2004; 175:189-202.

53. Davis CL, Gutt M, Llabre MM, Marks JB, O'Sullivan MJ, Potter $\mathrm{JE}$ et al. History of gestational diabetes, insulin resistance and coronary risk. J Diabetes Complications. 1999;13:216-23.

54. Noussitou P, Monbaron D, Vial Y, Gaillard RC, Ruiz J. Gestational diabetes mellitus and the risk of metabolic syndrome: a population-based study in Lausanne, Switzerland. Diabetes Metab. 2005;31:361-9.

55. Cnattingius S, Mills JL, Yuen J, Eriksson O, Salonen H. The paradoxical effect of smoking in preeclamptic pregnancies: smoking reduces the incidence but increases the rates of perinatal mortality, abruptio placentae, and intrauterine growth restriction. Am J Obstet Gynecol. 1997;177:156-61.

56. Yang Q, Wen SW, Smith GN, Chen Y, Krewski D, Chen XK et al. Maternal cigarette smoking and the risk of pregnancy-induced hypertension and eclampsia. Int J Epidemiol. 2006;35:288-93.

57. Lindqvist PG, Marsal K. Moderate smoking during pregnancy is associated with a reduced risk of preeclampsia. Acta Obstet Gynecol Scand. 1999;78:693-7.

58. Odegard RA, Vatten LJ, Nilsen ST, Salvesen KA, Austgulen R. Risk factors and clinical manifestations of pre-eclampsia. BJOG. 2000;107:1410-6.

59. Hammoud AO, Bujold E, Sorokin Y, Schild C, Krapp M, Baumann $P$. Smoking in pregnancy revisited: findings from a large population-based study. Am J Obstet Gynecol. 2005;192:1856-62.

60. Conde-Agudelo A, Althabe F, Belizan JM, Kafury-Goeta AC. Cigarette smoking during pregnancy and risk of preeclampsia: a systematic review. Am J Obstet Gynecol. 1999;181:1026-35.

61. Castles A, Adams EK, Melvin CL, Kelsch C, Boulton ML. Effects of smoking during pregnancy. Five meta-analyses. Am J Prev Med 1999; 16(3):208-215.

62. England LJ, Levine RJ, Qian C, Soule LM, Schisterman EF, Yu $\mathrm{KF}$ et al. Glucose tolerance and risk of gestational diabetes mellitus in nulliparous women who smoke during pregnancy. Am J Epidemiol. 2004;160:1205-13.

63. Cnattingius $S$, Lambe $M$. Trends in smoking and overweight during pregnancy: prevalence, risks of pregnancy complications, and adverse pregnancy outcomes. Semin Perinatol. 2002;26:286-95.

64. Terry PD, Weiderpass E, Ostenson CG, Cnattingius S. Cigarette smoking and the risk of gestational and pregestational diabetes in two consecutive pregnancies. Diabetes Care. 2003;26:2994-98.

65. Xiong X, Saunders LD, Wang FL, Demianczuk NN. Gestational diabetes mellitus: prevalence, risk factors, maternal and infant outcomes. Int J Gynaecol Obstet. 2001;75:221-8. 
66. Doherty DA, Magann EF, Francis J, Morrison JC, Newnham JP. Pre-pregnancy body mass index and pregnancy outcomes. Int J Gynaecol Obstet. 2006;95:242-7.

67. Hackmon R, James R, O'Reilly GC, Ferber A, Barnhard Y, Divon $\mathrm{M}$. The impact of maternal age, body mass index and maternal weight gain on the glucose challenge test in pregnancy. J Matern Fetal Neonatal Med. 2007;20:253-7.

68. U.S.Department of Health and Human Services, Public Health Service, Office of the Surgeon General. Women and smoking: A report of the Surgeon General. Rockville, MD: U.S. Dept. of Health and Human Services, Public Health Service, Office of the Surgeon General, 2001.

69. Nicklas BJ, Tomoyasu N, Muir J, Goldberg AP. Effects of cigarette smoking and its cessation on body weight and plasma leptin levels. Metabolism. 1999;48:804-8.

70. Qiu C, Sorensen TK, Luthy DA, Williams MA. A prospective study of maternal serum C-reactive protein (CRP) concentrations and risk of gestational diabetes mellitus. Paediatr Perinat Epidemiol. 2004;18:377-84.

71. Wolf M, Sandler L, Hsu K, Vossen-Smirnakis K, Ecker JL, Thadhani R. First-trimester C-reactive protein and subsequent gestational diabetes. Diabetes Care. 2003;26:819-24.

72. Wolf M, Sauk J, Shah A, Vossen SK, Jimenez-Kimble R, Ecker $\mathrm{JL}$ et al. Inflammation and glucose intolerance: a prospective study of gestational diabetes mellitus. Diabetes Care. 2004;27:21-7.

73. Lain KY, Luppi P, McGonigal S, Roberts JM, Deloia JA. Intracellular Adhesion Molecule Concentrations in Women Who Smoke During Pregnancy. Obstet Gynecol. 2006;107:588-94.

74. Hotamisligil GS. Inflammation and metabolic disorders. Nature. 2006;444:860-7.
75. Hotamisligil GS. Inflammatory pathways and insulin action. Int J Obes Relat Metab Disord. 2003;27 Suppl 3:S53-5.

76. Saeed RW, Varma S, Peng-Nemeroff T, Sherry B, Balakhaneh $\mathrm{D}$, Huston $\mathrm{J}$ et al. Cholinergic stimulation blocks endothelial cell activation and leukocyte recruitment during inflammation. J Exp Med. 2005;201:1113-23.

77. Meisinger $\mathrm{C}$, Doring A, Thorand B, Lowel H. Association of cigarette smoking and tar and nicotine intake with development of type 2 diabetes mellitus in men and women from the general population: the MONICA/KORA Augsburg Cohort Study. Diabetologia. 2006;49:1770-6.

78. Klemmensen AK, Olsen SF, Osterdal ML, Tabor A. Validity of preeclampsia-related diagnoses recorded in a national hospital registry and in a postpartum interview of the women. Am J Epidemiol. 2007;166:117-24.

79. Dolea C, AbouZahr C. Global Burden of Hypertensive Disorders in Pregnancy in the Year 2000. GBD 2000 Working Paper. 2003. Geneva, World Health Organization.

80. Cedergren M. Effects of gestational weight gain and body mass index on obstetric outcome in Sweden. Int J Gynaecol Obstet. 2006;93:269-74.

81. Doherty DA, Magann EF, Francis J, Morrison JC, Newnham JP. Pre-pregnancy body mass index and pregnancy outcomes. Int J Gynaecol Obstet. 2006;95:242-7.

\section{Correspondence to:}

Eliana Wendland. Programa de Pós-Graduação em Epidemiologia. Universidade Federal do Rio Grande do Sul. Rua Ramiro Barcelos, 2600/414, 90035-003, Porto Alegre, RS.

Email: eliana.wendland@ufrgs.br 